\title{
Operational Change and American Grand Strategy in the Context of the China Challenge
}

With fiscal pressures at home and China's continued rise abroad, the United States shows no signs of wanting to reverse its costly grand strategy of deep engagement. In the context of America's relative decline, we evaluate existing proposals to ease pressures on the United States. We argue that the key aspects of American decline are in fact often operational rather than strategic in nature, consequently the undifferentiated fashion in which rise and decline is often presented is neither useful in describing current changes nor in proposing how to address them. Problems at the operational level do not necessarily demand higher-level strategic level alterations. As such, while restructured forms of deep engagement will help alleviate resource constraints in the medium to long term, their utility in addressing the operational changes brought on by relative decline are less apparent. Given that resource constraints are therefore not necessarily the primary concern, the major strategic elements of American deep engagement are more durable than commonly supposed. America's current strategic objectives are not constrained by changes brought on by its relative material decline with respect to China, but by changes in the operational environment. 
Advocates of American retrenchment have argued that in the context of a rising China and associated relative decline, its strategic objectives should be fundamentally re-thought and greatly moderated; absent a significant threat in "Europe, East Asia, or the Persian Gulf, there is little reason to deploy US ground or air forces in these regions and little need for a vast military establishment here at home". ${ }^{1}$ During his campaign, President Trump borrowed from this retrenchment school when he promised to abrogate America's costly security alliances and put military free-riders on notice. Despite these promises however, and once in office, President Trump has increased defense spending, further extended America's deployment to Afghanistan and reinforced American security commitments around the world. As such, if we can identify a 'Trumpian' foreign security policy worldview, it looks very much like a continuity of America's long standing grand strategy of 'deep engagement'. ${ }^{2}$ American foreign policy thus faces an ongoing structural problem: how to reconcile this continuing and longstanding commitment to its global deep engagement in the context of shifts in the international distribution of power. In short, how to continue to do what it wants in what is becoming an ever more constrained international environment.

In response to this pressing problem a number of theorists have called for a more regionally sensitive American engagement, with changes in global force posture to upgrade some regions, whilst downgrading others. The logic is that in the absence of strategic moderation in the US's expansive goals of deep engagement, it should be more regionally sensitive with some areas of the globe holding greater national security weight than others. By increasing its 'bandwidth' in important regions, America can thus allegedly respond to relative decline whilst maintaining its

\footnotetext{
${ }^{1}$ Walt, Stephen M. "US Grand Strategy after the Cold War: Can Realism Explain It? Should Realism Guide It?" International Relations, vol. 32, no. 1, 2018, p.13; See also John Mearsheimer and Stephen Walt, "The Case for Offshore Balancing: A Superior U.S. Grand Strategy" Foreign Affairs July/August (2016) pp, 70-83; Barry Posen, Restraint: A New Foundation for U.S. Grand Strategy (Ithaca: Cornell University Press, 2014); Christopher Layne, "The Unipolar Illusion: Why New Great Powers Will Rise" International Security 17:4 (1993) pp, 5-51 ; Christopher Layne, "From Preponderance to Offshore Balancing: America's Future. Grand Strategy,", International Security, Vol. 22 No. 1 (summer 1997), p.86-124 ; Christopher Layne, 'America's Middle East Grand Strategy After Iraq: The Moment for Offshore Balancing', European Journal of International Relations June 2007 vol. 13 no. 2 pp. 155-185

2 Stephen Brooks, William Wohlforth, and John Ikenberry, "Don't Come Home, America: The Case Against Retrenchment" International Security 37:3 (2012/13) pp, 7-51
} 
longstanding global commitments. This paper explores this puzzle and asks, in the context of a continued commitment to global deep engagement, can the regional reallocation of America's military capacity help alleviate some of the constraints imposed by its relative decline?

We develop three arguments. First, we argue that proposals for restructured forms of American engagement not only offer limited resource savings but may not address the underlying issues associated with relative decline at all. Second, we demonstrate that the important consequences of relative decline are not in fact primarily strategic in nature. Instead, we develop the argument that operational factors including technological innovation and the evolution of operational practices present the biggest constraint on American objectives rather than aggregate resource constraints per se. By extension, arguments about US relative decline are being operationalised at the wrong (strategic) level of analysis. Third, durability is largely associated with stocks of capabilities vis-vis over major powers (an effectively zero-sum relative resource perspective). However, when viewed from the operational level, the military strategy attending deep engagement appears more durable. In short, the United States faces operational constraints rather than strategic ones and as such, strategic level changes relating to objectives and overall approach are unnecessary unless it is an alteration in strategic objectives themselves that are desired.

We proceed in four parts. The first section describes the nature of relative decline, discusses its purported effects, and displays data on its extent. We then move on to discuss what options implementers and proponents of contemporary core strategic objectives and approaches argue are available to the United States in dealing with relative decline. The third section then provides an evaluation of these proposals. Finally, we present our own analysis of how relative decline can be seen to be affecting US military strategy, describing the limitations of the extant approaches when addressing these issues, ending with a discussion regarding the implications of our findings for strategic studies and America's options. 


\section{What is Relative Decline?}

Relative decline refers to the situation in which a state's power, defined predominantly as economic output, decreases relative to other state's. Changes in international distributions of power often lead to calls for a recalibration of strategic ambition as the ends of strategy become less attainable via more constrained means. In short, "states, like firms, tend to go bankrupt when they budget blithely and live beyond their means." ${ }^{3}$ In the main, America's relative economic decline is largely a consequence of China's rapid economic growth, having increased its share of global GDP from approximately 5 percent in 1991 to around 15 as of 2016, whereas comparatively the United States currently sits at around 25 percent.

Despite these changes in GDP, some scholars have suggested that American relative decline may be overstated as "most studies do not look at a comprehensive set of indicators. Instead they paint impressionistic pictures of the balance of power...[that] conflate size with power and thereby overstate the capabilities of large but underdeveloped countries." ${ }^{4}$ That is, on several key indicators America's international economic power is underplayed by consulting key economic aggregates, particularly when the size of these aggregates is not adjusted for development level or population. For example, Beckley's work assesses America's global position in its totality rather than just with respect to its military dimensions. However, in doing so, the applicability of its results for understanding how US military strategy may be influenced by changes in economic aggregates is circumscribed. Why? The main reason is that irrespective of the composition of China's exports or its relative lack of triadic patents, ${ }^{5}$ the Chinese military now has access to greater and more technologically advanced resources which have produced rapid changes in the offensive and defensive capabilities of the People's Liberation Army (PLA). In short, irrespective of America's continued military and economic power advantages, the threat

\footnotetext{
${ }^{3}$ Paul MacDonald and Joseph Parent, "Graceful Decline? The Surprising Success of Great Power Retrenchment" International Security 35:4 (2011) p, 19

${ }^{4}$ Michael Beckley, “China’s Century? Why America’s Edge Will Endure” International Security 36:3 (2011/12) pp, 41-78.

5 Beckley, "China's Century?" 68-69
} 
environment today is not as hospitable as it was twenty, or even ten years ago. To what extent this process of relative degradation in American power will continue is a partially open question which will shall address later, but for the near term at least, there are no obvious signs of a sharp reversal of these growth dynamics.

As such, America's continued commitment to deep engagement may become increasingly resource intensive with its continued relative decline therefore likely to pull it into a resource allocation problem that may well generate a form of 'imperial overstretch' or a 'lippmann gap' an imbalance between "the nation's commitments and the nation's power." 6 In figure 1 we show changes in Chinese GDP and military spending over the last twenty years,

\section{Figure 1}

a)

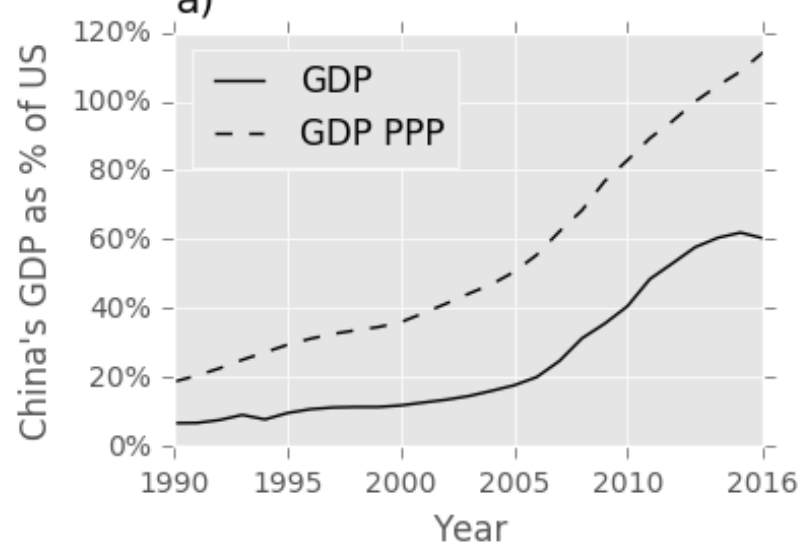

c) b)
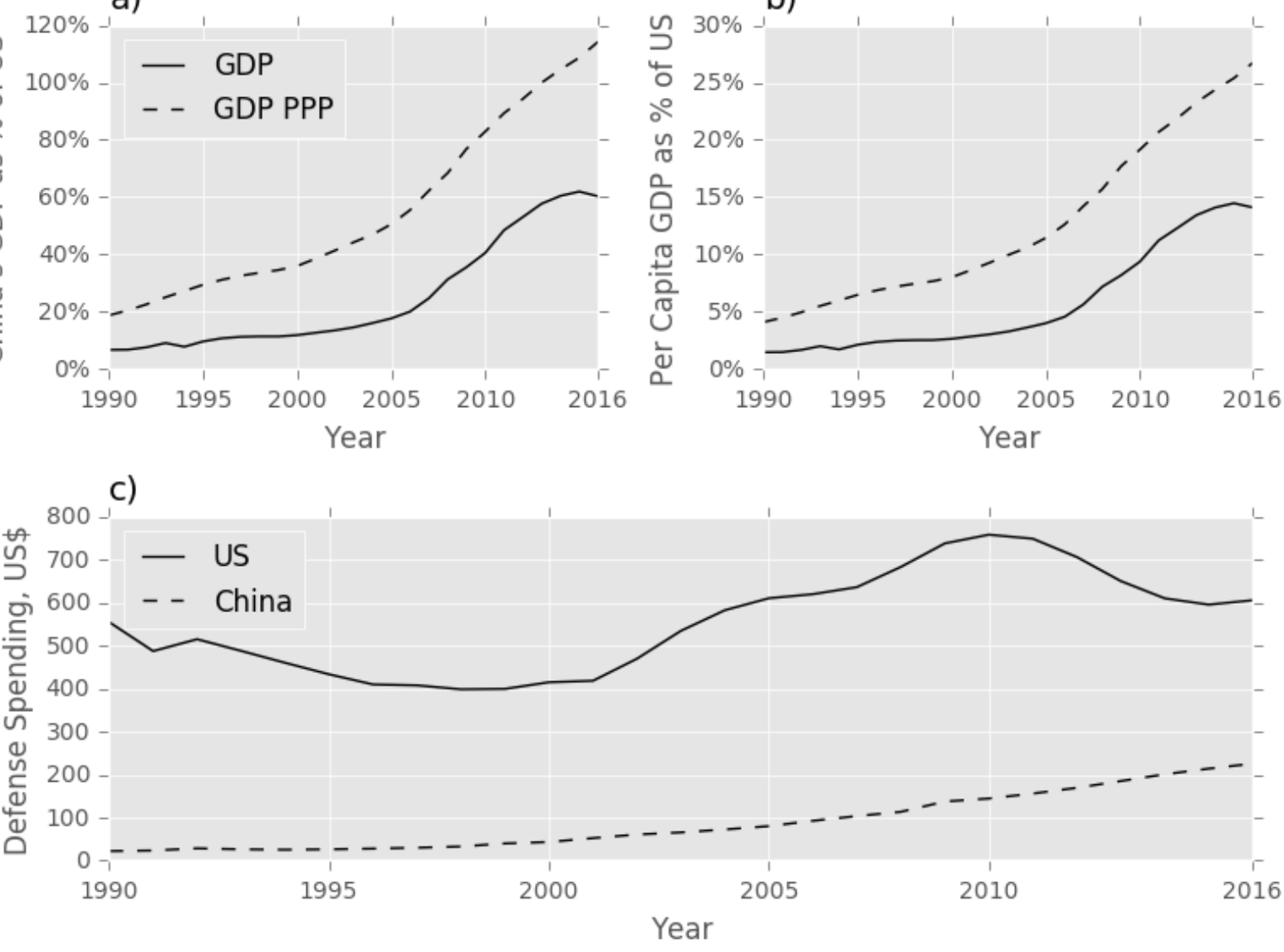

\footnotetext{
${ }^{6}$ Walter Lippmann, US Foreign Policy: Shield of the Republic (Boston: Little, Brown and Company, 1943) p, 9
} 
Panel 'a' shows Chinese GDP expressed as percent of the United States' both in current US dollars and after a Purchasing Power Parity (PPP) transformation. Panel ' $b$ ' then compares GDP per capita amounts, which are more indicative of development levels. Finally, panel 'c' displays US and Chinese military spending expressed in constant US dollars. What is immediately obvious is the effect of the PPP transformation, which nearly doubles Chinese GDP from its raw amount. This transformation is an artificial 'correction' that attempts to account for differing price levels in each state and so is normally used to indicate relative standard of living differences which may be hidden by referring to exchange rates alone. This is controversial for a number of reasons, not least because of measurement error, how representative the 'baskets of goods' used to create the transformation is, and how comparable price levels in profoundly different political economies really are. Nonetheless, both measures show a pronounced increase in Chinese GDP, and so both are indicative of some level of American relative decline.

This poses potential problems for the United States for several reasons, but in the main part because of how it may influence the feasibility of current strategic objectives and approaches. As it currently stands, the United States practices a variant of what is commonly known as deep engagement, in this case an expanded variant variously named 'liberal hegemony' or 'deep engagement plus'.7 This combines the general parameters of deep engagement - forward defense of key regions and allies, and active management and shaping of the global international economic order - with an expanded remit that involves a nearly open ended commitment to liberal interventions and active democracy promotion. While the Trump administration has curtailed some of these aspects, most current literature starts with this description of current US grand strategy as its point of departure. This then supposes expansive commitments to be married with increased latent and actualized capabilities of other states.

\footnotetext{
${ }^{7}$ Barry Posen use the former in his book Restraint, whereas Brooks and Wohlforth suggest the latter in their article, "The Rise and Fall of the Great Powers in the Twenty-first Century: China's Rise and the Fate of America's Global Position" International Security 40:3 (2015/16) p, 47
} 
In fact, one need not debate the above economic metrics to see that America's relative military position is facing additional constraints, it is only necessary to consider that Chinese military spending has increased substantially in the last decades and in a way that is less controversial than the aforementioned GDP metrics. While American expenditure is still many times higher, China's resources only need be projected regionally rather than globally - although corruption problems circumscribe how much of this expenditure is actually directed toward military capacity itself. ${ }^{8}$ While at present US resources remain considerable, they are currently geographically dispersed both physically and in their allocation to specific Combatant Commands. Moreover, growing Chinese power and an increasing emphasis on deterring Russia on NATO's Eastern flank will continue to demand more of the United States, thus generating rising opportunity costs for the stationing of US military forces and associated assets in a number of regions worldwide. How do proponents of deep engagement suggest responding to these trends?

\section{How Should the US Respond to Relative Decline?}

We now discuss a number of different proposals which share the common conceptual assumption that the US should seek to maintain core strategic objectives and approaches while reallocating or using current resources more efficiently. This is not just confined to theoretical discussions. Indeed, despite indications that the Trump administration may renege on major alliance commitments his administration has instead reinforced American force posture in a number of key regions. Specifically, he has increased the US's military commitment to Afghanistan by abandoning a 'timeline based strategy' to a 'conditions-based' strategy (effectively an open ended and raised US military presence). He has also increased the European Reassurance Initiative by $\$ 1.4$ billion to $\$ 4.7$ billion for 2018 whilst tightening sanctions on Russia and bombing Syria, ostensibly on humanitarian grounds. ${ }^{9}$ As such, we are not seeing major global readjustments on the part of the US.

\footnotetext{
${ }^{8}$ See, as an example, Demetri Sevastopulo, "China's Goldfinger general quizzed in corruption probe" Financial Times, January 15, 2014. https://www.ft.com/content/17808e4c-7dad-11e3-95dd-00144feabdc0\#axzz2usRIG2I7

9 On Trump's new Afghanistan strategy see see Muñoz, Carlo. "Pentagon Faces Hurdles Turning Trump's Afghanistan Strategy into Action." The Washington Times. The Washington Times, 29 Aug. 2017. Web. 30 Aug. 2017 http://www.washingtontimes.com/news/2017/aug/29/pentagon-faces-hurdles-turning-donald-trumps-afgha/;
} 
One variant proposed by leading deep engagement advocates Brooks and Wohlforth argues that America's problem is not currently one of limited resources but rather of the inefficient allocation of them. ${ }^{10}$ They believe that at present deep engagement's core objectives "have often taken a back seat in favor of a broader set of aims that includes preventing humanitarian crises and spreading liberal values."11 They call this approach 'deep engagement plus' to differentiate it from the more parsimonious, original deep engagement. As a consequence, any impending resource constraints could be addressed merely by a restriction on these activities and to avoid the often costly forms of liberal humanitarian intervention or democratic 'nation building'. In particular, they note that "military requirements that might seem daunting for deep engagement plus become far more modest if the aim is to pursue the defensive goals of deep engagement." 12

An alternative to this perspective, and one which intends to respond to more severe resource constraints, can be found in the broader theoretical literature on retrenchment and military strategy. While the general scholarship on US strategic retrenchment is based upon an undifferentiated approach to retrenchment across global responsibilities, advocates of activist deep engagement grand strategies would logically prefer limited and regionally sensitive recalibrations of US force posture not least as states "retain a vital interest in maintaining the status quo order in the regions currently under their protection. As such, declining states will only withdraw from a region voluntarily if they expect their preferred order to survive this withdrawal."13 Haynes work has proposed a more regionally focused and refined model for the process of retrenchment and suggests assessing regions for a suitable 'successor state' with

\footnotetext{
On the European Reassurance Initative see "2018 Budget Request for European Reassurance Initiative Grows to \$4.7." U.S. DEPARTMENT OF DEFENSE. 01 June 2017. Web. 30 Aug. 2017. https://www.defense.gov/News/Article/Article/1199828/2018-budget-request-for-european-reassurance-initiativegrows-to-47-billion/

${ }^{10}$ Brooks and Wohlforth, "The Rise and Fall of the Great Powers in the Twenty-first Century: China's Rise and the Fate of America's Global Position", 7-53

11 Brooks and Wohlforth, "The Rise and Fall of the Great Powers in the Twenty-first Century: China's Rise and the Fate of America's Global Position", 47

12 Brooks and Wohlforth, "The Rise and Fall of the Great Powers in the Twenty-first Century: China's Rise and the Fate of America's Global Position", 49

${ }^{13}$ Kyle Haynes, "Decline and Devolution: The Sources of Strategic Military Retrenchment" International Studies Quarterly 59 (2015) p,490
} 
compatible interests and sufficient power capabilities to retain order in the given region during and after the process of retrenchment. ${ }^{14}$ Principally, this "depend[s] upon the availability of powerful and closely allied 'successor states' to which the declining state can devolve its regional responsibilities." 15 In this way, resource constraints and changes in relative power can be addressed through the withdrawal of forces from regions of lesser perceived importance to enable relocation to regions where they are needed more urgently. By doing so, central strategic objectives and approaches may be maintained, albeit at the cost of global coverage.

To an extent, this more regionally sensitive approach has been adopted by the US Department of Defence (DoD) that altered the implementation of their military strategy through changes in force posture. Conceptually this presupposes that permanent stationing may be replaced by rotational deployments as a way to ease resource constraints and increase flexibility. The original intention of which was to create "a more flexible and effective force posture" in reflection of the belief "that the 21st century does not call for the permanent deployment of heavy forces." Indeed, in many cases the defense establishment believed that they could actually more readily deploy heavy units from the continental United States (CONUS) with new and better integrated strategic lift assets, insisting that "the decrease in overall numbers in the theater will be offset not only by the retention of inherently expeditionary units such as airborne brigades, aviation units, and naval forces, but also by the introduction of our most modern transformed forces." 16 How effective would they be in achieving their stated aims and would these approaches resolve the problems posed by relative decline? In the next section of the paper we examine this puzzle.

\section{How do existing proposals stack up?}

Existing proposals or resolutions to emergent resource constraints are based on the premise that existing resources can be more efficiently used to address central strategic concerns. However,

\footnotetext{
${ }^{14}$ Haynes, "Decline and Devolution," 493-495

${ }^{15}$ Haynes, "Decline and Devolution," 490

${ }^{16}$ Donald Rumsfeld, testimony before the Senate Armed Services Committee hearing on "The Global Posture Review of United States Military Forces Stationed Overseas," September 23, 2004.

https://www.gpo.gov/fdsys/pkg/CHRG-108shrg23080/html/CHRG-108shrg23080.htm
} 
they differ in the manner in which these resources are to be efficiently allocated. The basic logic of the three mentioned earlier is as follows. First, the DoD believed that the US could benefit from efficiency savings via reducing forward presence abroad through rotational and 'surge capable' forces. Second, Brooks and Wohlforth's logic presupposes that winding down 'liberal hegemonic' interventions would likewise free-up resources to be used elsewhere. And finally, the regional retrenchment model goes a step further and explicitly suggests that core strategic objectives could be maintained via limiting the geographic scope to which they are applied. That is, through withdrawing from a given region to buttress presence elsewhere. In short, what connects all three is a belief that present resources are sufficient to achieve given strategic objectives subject to a specific constraint. However, how likely are these proposals to achieve these aims?

\section{DoD Force Posture Alterations}

DoD efforts to implement 'a more flexible and effective force posture' which could surge military forces to given regions if and when contingencies emerged have not proved to be all that successful. Indeed, a recent report authored by John Deni from the US Army War College concludes that "recent evidence essentially undermines the claims made in 2003-2004 and again in 2010-2011 that the Department of Defense (DoD) could achieve key objectives such as deterrence and assurance more effectively and efficiently through increased reliance on Army rotational presence in lieu of forward stationing." 17

Using a wide range of data sources, including two to three years of data from US army rotations to Europe and South Korea, the report suggests that rotational presences do not offer the financial savings promised, nor offer the level of assurance to allies that permanent stationing does. ${ }^{18}$ As an example, the report relays data suggesting that the annual cost of rotational deployments to Europe of an Armoured Brigade Combat Team (ABCT) were priced at $\$ 1,191$

\footnotetext{
${ }^{17}$ John Deni, "Rotational Deployments vs. Forward Stationing: How Can The Army Achieve Assurance and Deterrence Efficiently and Effectively?" Strategic Studies Institute and U.S. Army War College Press, August 2017. p, xvii

${ }^{18}$ Deni, "Rotational Deployments", xvii-xx
} 
million, while forward stationing the unit in Germany would cost \$1,056 million annually, largely due to the costs of shipping armoured units back and forth between CONUS and Europe. ${ }^{19}$ More importantly, Deni's report argues that recipient nation's perceived rotational presence represent less of a commitment than permanent stationing of US forces, potentially undermining the assurance mechanism that these defence commitments are intended to create. ${ }^{20}$ These findings corroborate the findings of an earlier report issued by RAND also investigating the relative costs and benefits of the overseas basing of US military forces that suggest that "generally...the savings produced by merely realigning forces while keeping installations open is not sufficient to offset the cost of pricing full presence through rotational deployments." ${ }^{21}$

However, as both reports note, costs are only half of the picture. Different stationing practices also represent advantages and disadvantages with respect to political and military considerations, be that the risk of closure of access to forward bases or anti-access/area denial (A2AD) threats to such installations, both of which have past and current relevance. Not only has the United States faced prior issues (albeit of varying degrees) with forward stationing in Japan and the Philippines, but Chinese A2AD capabilities put a number of these bases and units at risk of preventive or preemptive attack. ${ }^{22}$ Indeed, one need only consider that a military base is effectively a predesignated aimpoint for a missile strike to see why operating close to a potential adversaries territory could become problematic. However, the most important factor, is that irrespective of costs, the growing A2AD threat, or political risk, rotational or permanent presence both imply effectively similar allocation of forces. That is, irrespective of whether forces are based in the CONUS or forward deployed, force structure and equipment procurement has to be shaped toward executing a given global military strategy. This in practice means that whether or not forces are forward deployment or not, overall U.S. force structure will have to support deploying

\footnotetext{
${ }^{19}$ Deni, "Rotational Deployments", 22

${ }^{20}$ Deni, "Rotational Deployments", 31

${ }^{21}$ Michael Lostumbo, Overseas Basing of U.S. Military Forces: An Assessment of Relative Costs and Strategic Benefits (RAND: Santa Monica, 2013) p,233

22 Stephen Biddle and Ivan Oelrich provide an up-to-date and comprehensive overview, "Future Warfare in the Western Pacific: Chinese Antiaccess/ Area Denial, U.S. AirSea Battle, and Command of the Commons in East Asia" International Security 41:1 (2016) pp, 7-48
} 
to a given region in case of a given security contingency. This issue, which we shall discuss in further detail further on, also arises in the other options we analyse.

\section{How viable is 'Regional Retrenchment'?}

The premise of regional retrenchment is that a declining power can regionally triage retrenchment to buttress key regions and strategic objectives. However, the capacity to do so effectively relies on a number of difficult to assess assumptions concerning economic interests and regional security orders - principally that of economic interest and perceived geopolitical stability. This therefore invites uncertainty and risk, particularly if regional retrenchment is premised on stability and continued access post-withdrawal. In what follows, we demonstrate these shortcomings through attempting to calculate the necessary indices relating to such economic and security interests that such an approach requires.

For an index of economic interests we focus on major economic variables so as to permit regional comparison along principal components of economic interest. Specifically we settle on a combination of overall trade, foreign direct investment (FDI) stocks, and portfolio investment. Trade is inclusive of imports and exports, whereas FDI refers to outward stocks only - that is, US investments in other regions. Finally, portfolio investment refers to outward US investments that are not considered FDI, in this case equities, and long and short term debt securities. The index then weights the three components to return a single figure. ${ }^{23}$ To measure the security environment of a region we then look at the distribution of economic resources within a region via a 'Herfindahl-Hirschman Index' (HHI) which provides a scale of relative concentration from zero to one. Next, we use a measure of latent economic power due to number of empirical difficulties with measures of military power that have manifested themselves repeatedly throughout scholarship and government research. ${ }^{24}$ For example, the fact that military spending

\footnotetext{
${ }^{23}$ In the absence of a clear theoretical reason for selecting a given weight for each component we initially set the index at a third per component, we then undertook a permutation test which randomly reassigned the weighting of each component, recorded the figure and then averaged the results. The outcome of a thousand permutations indicated that the ordinal ranking of the index was unaffected, suggesting that a third per component offered an index robust to differences in the weighting scheme. A boxplot of the results may be found in appendix 1 .

${ }^{24}$ For a brief discussion please see Appendix 2.
} 
does not provide an entirely useful metric for understanding relative military power between two given countries, or indeed a collection thereof. ${ }^{25}$

To do so we calculate two $\mathrm{HHI}$ indexes, one which simply uses nominal GDP alone and another which corrects for relative size and development, in this case derived from GDP conditioned on GDP per capita. Following Beckley's criticism, by conditioning upon GDP per capita we can attempt to account for the fact that a state with a large population relative to its GDP will have a lower level of economic development than a country with the same GDP but a smaller population. ${ }^{26}$ For example, GDP per capita can offer us a rough indication as to the development of a given state, with higher GDP per capitas broadly indicative of greater individual wealth and technological advancement. By doing so, we can then assess how concentrated power is within each region on the presumption that more balanced power is preferred to concentration. In both the case of the $\mathrm{HHI}$ index and the economic index the results we display are scaled with respect to the leading region, returning an index from zero to one.

The index of economic interest, displayed panel ' $a$ ' of figure 2, returns what would be rather intuitive results. In this case that Europe represents the most economically important region to the United States as of 2016. In particular, FDI and portfolio investment in this region is far greater than anywhere outside of North America. This is closely followed, as we can see, by the Asia Pacific. Both of which are in keeping with expectations. However, while the index accurately captures much of what could be considered 'major economic interest' there are a few notable exceptions that could complicate the picture. Most obviously, aggregated trade indices do not account for the fact that certain products, like oil, are poorly substitutable between regions. With the majority of US supply coming from much nearer to home, this may not directly matter so much to the United States, but it may have broader 'knock on' effects to allies and the global

\footnotetext{
${ }^{25}$ Starting in the Cold War, the US Department of Defence initiated net assessment exercises to evaluate America's military balance with its peers, quickly finding that military spending aggregates offered poor face validity for military power. See, Andrew Krepinevich and Barry Watts, The Last Warrior: Andrew Marshall and the Shaping of Modern American Defense Strategy (New York: Basic Books, 2015)

${ }^{26}$ Michael Beckley, "Economic Development and Military Effectiveness" Journal of Strategic Studies 33:1 (2010) pp, 43-79.
} 
economy more generally. For example, East Asia and Europe are highly dependent on oil from the Middle East which affects them economically, but may also contribute to influence them politically. For this reason, the United States still has significant interests in the Middle East despite apparently low trade levels and investments. The sustainment of an American-led 'positive sum' order is a hard to quantify, yet significant, economic and strategic interest of the United States.

\section{Figure 2}

a)

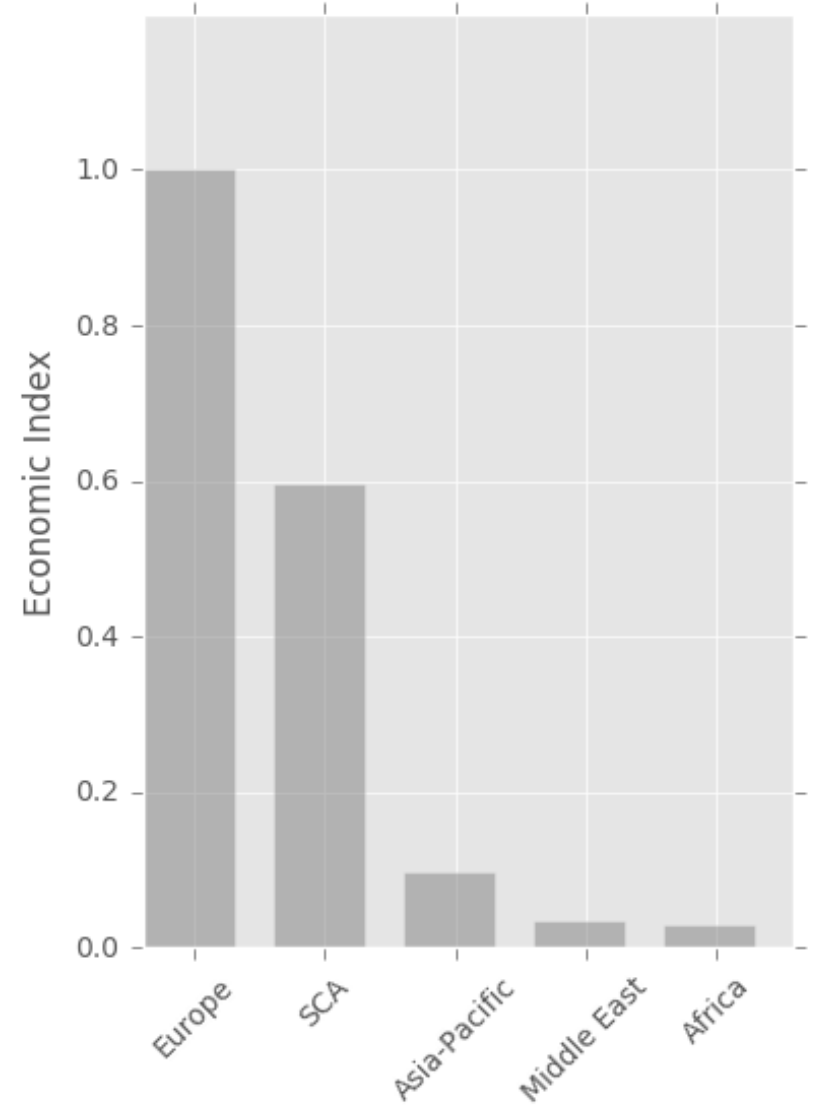

b)

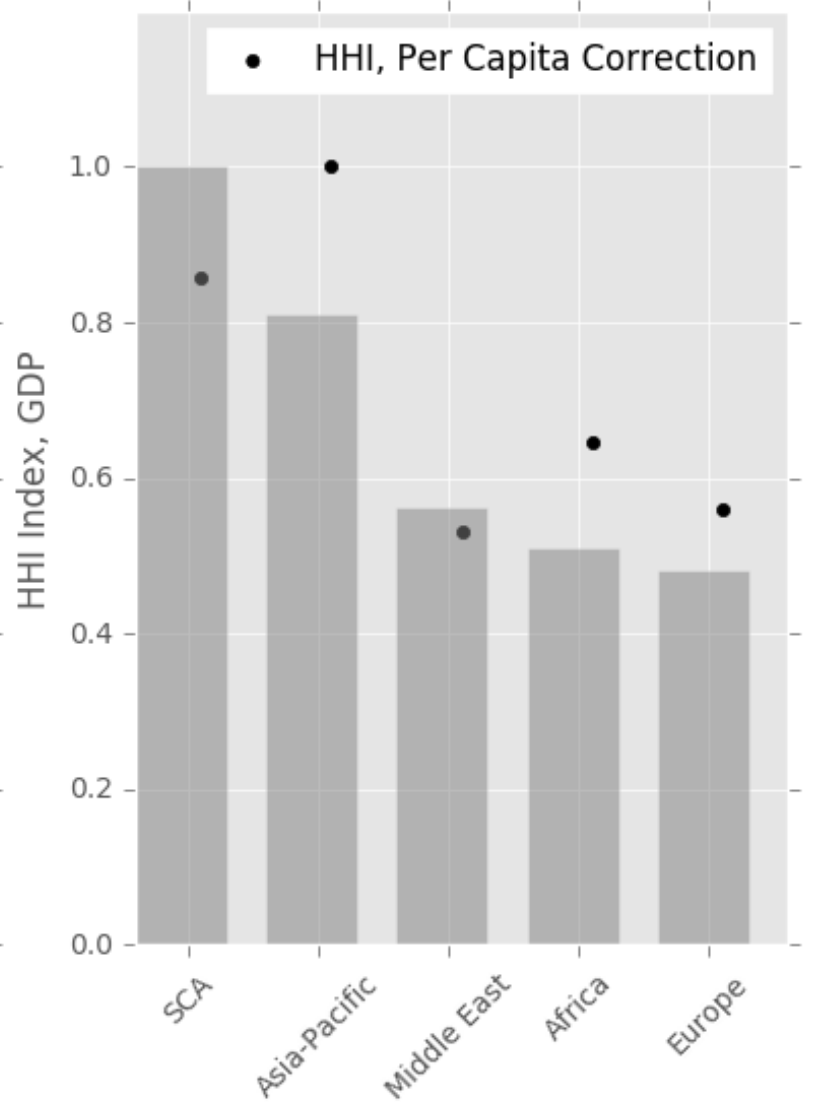

Likewise, as shown panel ' $b$ ' of figure 2, a rough estimation of economic power concentration (the security focused index) presents us with some interesting results. As we can see, East Asia has the most pronounced discrepancy in power of the regions analysed via GDP. There are two large powers of comparable sizes - China and Japan - which are large not only with respect to 
their region but also globally. This is closely followed by South and Central America (SCA), which has a major power discrepancy due to the size of Brazil relative to other regional states. According to standard balance of power logic, this implies that East Asia is the main threat area whilst other theatres, particularly Europe, are more stable. Not only is there a sizable power asymmetry in the region, but its overall economic size makes it more problematic than the SCA region whose aggregate economic size is smaller than Japan's GDP. But how well does this index actually capture security dynamics?

To an approximation the index reflects some underlying dynamics suppressed by looking at current military capabilities, particularly in East Asia. For example, Japan currently spends about $1 \%$ of its GDP on defence and has done so since $1960 .{ }^{27}$ However, our index reminds us that not only is the Japanese economy large both relative to its region and globally, but it also has a very high level of development, hence its large weighting on the index with respect to China. Likewise, and reflecting the critiques of retrenchment advocates, we also see that Europe has a number of states which have medium to large economic sizes. Indeed, Russia is not even included in the top five in this region.

Yet this is only a static analysis, with the balances displayed here subject to alter significantly over the coming decade/s, begging the question as to how knowledge of current dynamics allows us to infer about the future. This in turn leads us to ask whether such a measure can provide useful insights on past data. A pertinent example would be Europe in the period leading up to the Second World War, a relatively short time frame that is broadly well known and of considerable strategic and political importance. Using the Maddison historical GDP database it is possible to recalculate the latent economic power index for regional states and assess whether and how well it allows us to predict the manner in which the region's dynamics changed over this timeframe. As we can see in table 1, in 1933 the largest European states (in descending order) were the United Kingdom, Germany, France, the USSR, and Italy. By 1939, while Germany had replaced

27 SIPRI, "SIPRI Military Expenditure Database 2017" https://www.sipri.org/databases/milex 
the UK as the largest state in our index, the more general ordinal ranking had not changed significantly. However, what had happened, as we can see in the fourth column (change), is that two of the region's states, the USSR and Germany, had grown disproportionately faster than the others.

\section{Table 1}

\begin{tabular}{c|ccc|}
\hline \multicolumn{2}{c}{ State } & 1933 & \multicolumn{2}{c}{1939} & Change \\
\hline United Kingdom & $1.2 \mathrm{e}+09$ & $1.8 \mathrm{e}+09$ & $45 \%$ \\
Germany & $8.3 \mathrm{e}+08$ & $2.0+\mathrm{e} 09$ & $142 \%$ \\
France & $7.5 \mathrm{e}+08$ & $9.6 \mathrm{e}+08$ & $27 \%$ \\
USSR & $3.9 \mathrm{e}+08$ & $9.6 \mathrm{e}+08$ & $143 \%$ \\
Italy & $3.5 \mathrm{e}+08$ & $5.4 \mathrm{e}+08$ & $54 \%$ \\
\hline HHI & 0.244 & 0.240 & $-1.4 \%$ \\
\hline
\end{tabular}

However, as shown by the HHI calculation, major discrepancies in the region's economic power actually decreased between 1933 and 1939, bringing it more in to balance. Yet as we know from the historical record the region had actually become critically volatile over this time frame. This has a number of important implications, but primarily suggests that qualitative information is likely to dominate the interpretation of such indices. Indeed, as Schweller has argued, often what is important is not material balances in themselves but rather how they are expressive of a 'balance of interests' ${ }^{28}$ That is, how the powers of revision and status quo are matched either regionally and/or globally. In this case, we see the rise of two revisionist powers - Germany and the USSR. More importantly, perhaps, we also see that by 1939 the perception of one power in particular, Germany, is that it expected an imminent and pronounced decline in its relative

\footnotetext{
${ }^{28}$ Randall Schweller, Deadly Imbalances: Tripolarity and Hitler's Strategy of World Conquest (New York: Columbia University Press, 1998)
} 
material capacity. ${ }^{29}$ According to Dale Copeland's 'dynamic differentials theory' this helps to explain why Germany launched the war when it did, despite a distribution of power which should have dissuaded it from doing so. Copeland suggests that "the probability of major war increases when decline is seen as deep and inevitable"${ }^{30}$, and at that time Germany perceived that its material advantages were likely to wane, principally in relation to the USSR who it also feared for ideological and racial reasons. Intuitively, if one were to think like this, the time to attack would be now, before degradation in material power becomes pronounced. Leading qualitative information to dominate the analysis.

In short, we find that material indices may suffer from face validity issues as well as generalisability problems despite offering intuitive static results. This is because some of the most important factors to consider in analyzing regional security dynamics are qualitative and intersubjectively formed (often at the national level). Moreover, measuring and projecting relevant variables into the future ranges from difficult to implausible. For these reasons, relying on these indices alone, or any index, to gauge medium-to-long term security dynamics is likely to provide unreliable and potentially unrealistic information. In turn, this adds to the risk profile of these options and subsequently influences their strategic utility. Thus, highlighting the need for significant trade-offs to justify potential risks, particularly given our working assumption that continuity in main strategic objectives is desired by contemporary political and economic elites.

\section{Are there significant resources available for reallocation?}

A central theme common to the above approaches concerns the resources available for reallocation. As we covered earlier, the United States rationalised changes in force posture on the belief that they could more readily deploy heavy armoured units from the continental United States (CONUS) with the help of new and better integrated strategic lift assets, using expeditionary forces to surge into areas where needed. Because of this, fewer forces are actually directly forward deployed on a permanent basis, with a leaner force posture providing forward

\footnotetext{
${ }^{29}$ Dale Copeland, The Origins of Major War (Ithaca: Cornell University Press, 2000) Chapter 5

${ }^{30}$ Copeland, The Origins of Major War, 15
} 
presences that can be expanded when necessary yet requiring lower day-to-day force levels. More importantly, as we can see in table 2, the main locations of these military personnel are in the two primary regions of interest to the United States: Europe and East Asia.

Table 2 - Total Military Personnel Permanently Deployed Abroad, Top Five Locations

\begin{tabular}{|l|l|c|}
\hline \multirow{2}{*}{ State } & \multicolumn{2}{|c|}{ Strategic Purpose: } \\
\cline { 2 - 3 } & Deterrence/Assurance & Counter Terrorism \\
\hline
\end{tabular}

Japan

Germany

South Korea

Italy

Afghanistan
39,623

34,399

23,297

11,806

Source: Defense Manpower Data Center,"Military and Civilian Personnel by Service/Agency by State/Country, as of June 2017" https://www.dmdc.osd.mil/appj/dwp/dwp reports.jsp

Notes: Category 'Unknown' has been omitted. It is, however, the third overall largest.

This implies that there may be fewer opportunities for savings or resource reallocation than one would initially imagine, yet it also reminds us that overall force structure is calibrated to the needs of military strategy, rather than regions in and of themselves. That is, the U.S. military's strategy objectives require the joint force to be able to tackle two regional adversaries simultaneously,

“...at any given time, our military will be capable of defeating a regional adversary in a large-scale, multi-phased campaign while denying the objectives of - or imposing unacceptable costs on - another aggressor in a different region." 31

\footnotetext{
31 Joint Chiefs of Staff, "The National Military Strategy of the United States of America 2015" U.S. Department of Defense, June 2015. p,6
} 
This in turn dictates specific, and rather large, force structure requirements besides any given regional forward presence. For example, consider the demands of current maritime strategy. At present this requires both the forward presence of an aircraft carrier in Japan and rotational deployments of a carrier to the Middle East. In addition to which, it further demands broader forward deployed and rotational naval forces at both of these locations and, as of 2015, to Europe as well. ${ }^{32}$ Given the demands of maintenance and training, these deployments can necessitate large force structures, particularly if the method of forward presence depends on rotations. ${ }^{33}$

These demands are pronounced for aircraft carriers, whose maintenance and training periods take up even larger amounts of time, and whose capabilities are regularly called upon. ${ }^{34}$ U.S. aircraft carriers undertake regularly scheduled deployments to various fleet areas of responsibility, supporting ongoing operations and demonstrating U.S. Navy capabilities. They also offer a 'surge' capacity to any given region to reinforce ongoing or upcoming combat operations as well as respond more generally to evolving crises. This has two implications for our analysis. Firstly, it dictates that the rotational deployment of an aircraft carrier to the Middle East is an important additional commitment that is missed by looking at permanently based troops alone. And secondly, individual adjustments are unlikely to make a huge difference to overall force structure. Indeed, it is interesting to note that recent reviews and analyses of future U.S. Navy force structure are working on the assumption that an additional carrier strike group (CSG) may be required to be committed to Europe, necessitating one new carrier, or up to two ${ }^{35}$ (albeit noting that forward homeporting of these vessels in the Mediterranean could notably reduce the additional ships required). ${ }^{36}$ This in turn suggests that a retrenchment from the Middle Eastern theatre could help free up current resources, but only in such a way which would bring force structure requirements back to the contemporary status quo.

\footnotetext{
${ }^{32}$ U.S. Navy, “A Cooperative Strategy for 21st Century Seapower” March 2015. http://www.navy.mil/local/maritime/150227-CS21R-Final.pdf

${ }^{33}$ Ronald O'Rourke, "Navy Force Structure: A Bigger Fleet? Background and Issues for Congress" Congressional Research Service, November 9, 2016.

${ }^{34}$ Roland Yardley, "Increasing Aircraft Carrier Forward Presence: Changing the Length of the Maintenance Cycle" RAND Corporation, 2008

${ }^{35}$ O’Rourke, "Navy Force Structure," 6

${ }^{36}$ O'Rourke, "Navy Force Structure," 3-10
} 
That notwithstanding, the resources so far spent on the Global War on terror (GWOT) are not insignificant. For example, while the current troop allocation to Afghanistan is currently near an all-time low, much like troop levels in Iraq, it has breached 100,000 in the recent past. ${ }^{37}$ Moreover, the Congressional Research Service (CRS) estimates that approximately $\$ 650$ billion in additional spending has been spent on conflict in Afghanistan alone from 2001 up until 2016. ${ }^{38}$ Given that the relative efficiency of spending a dollar on counter-terrorism abroad as opposed to at home has yet to be soundly established, this form of spending in itself could indeed provide a potential source of reallocation savings. Likewise, this form of expenditure innately involves opportunity costs relating to procurement, training, and basing which in themselves are likely to have had deleterious effects on the United States' response to China's rise.

Nonetheless, any savings that could be made from rotational presences and surge capacity do not address the fact that overall force structure and procurement are focused on the overall strategic objectives themselves, thus offering only limited potential savings. Moreover, with the improvement and diffusion of $A 2 A D$ technology worldwide, altering the implementation of force posture via rotations or skeletal presences accommodating additional 'surge capacity' may not prove sufficient to achieve the defensive goals of a deep engaged grand strategy over the long run. Likewise, this particular issue also manifests itself in Brooks and Wohlforth's suggestion to switch from a 'deep engagement plus' to a 'deep engagement' strategy focusing only on core commitments. In short, there are operational level concerns that are not addressed through changes at the strategic level alone.

The above has a number of implications. First, on their own terms the available reallocation options offer fewer resources than expected and second, these may entail unnecessary risks. However, more importantly for our paper is the question as to whether the principal effects of

\footnotetext{
${ }^{37}$ Lyne Williams and Susan Epstein, "Overseas Contingency Operations Funding: Background and Status" Congressional Research Service, February 7, 2017. pp, 19-21.

${ }^{38}$ Williams and Epstein, "Overseas Contingency Operations Funding," 16
} 
relative decline would be alleviated by changes in resources alone. We explore these dynamics in the following section.

\section{Relative Decline and the 'Levels of War'}

How well do declines in relative economic output underlie the military challenges the United States currently faces? Is it the case that the United States is simply short on resources, or are there other factors at play? The analysis and priorities of the US Department of Defense, alongside a growing academic literature suggest that aggregate resources in and of themselves are not the most pressing issue. ${ }^{39}$ For example, the main threat the United States military is currently responding to in relation to China is adapting to Antiaccess/Area-Denial capabilities, associated sensor networks, and other asymmetric forms of warfare. ${ }^{40}$ In fact, as Haddick has noted, some of these developments present considerable threats to US and allied forces at a relatively low cost. For example, the threat of swarm attacks from Chinese anti-ship cruise missiles offer the potential to overwhelm ship defenses from missiles that are both numerous and of little technological note. ${ }^{41}$

The implications of this are that the level of analysis at which these effects take place is arguably at the operational as opposed to grand strategic. The operational level of analysis is the bridge between strategy and tactics, that at which military operations are planned and executed (see table 3).

\section{Table 3}

\footnotetext{
${ }^{39}$ Michael Hutchens et al. "Joint Concept for Access and Maneuver in the Global Commons: A New Joint Operational Concept" Joint Force Quarterly 84 (2017) pp, 134-139 ; Stephen Biddle and Ivan Oelrich, "Future Warfare in the Western Pacific: Chinese Antiaccess/ Area Denial, U.S. AirSea Battle, and Command of the Commons in East Asia" International Security 41:1 (2016) pp, 7-48.

${ }^{40}$ For an overview, see Andrew Erickson et al. "Correspondence: How Good are China's Antiaccess/ Area-Denial Capabilities?" International Security 41:4 (2017) pp, 202-213

41 Robert Haddick, "China's Most Dangerous Missile (So Far)" War on the Rocks, July 2, 2014.

http://warontherocks.com/2014/07/chinas-most-dangerous-missile-so-far/; For more detail see Office of the Secretary of Defense, "Military and Security Developments Involving the People's Republic of China 2017" United States Department of Defense, 2017.

https://www.defense.gov/Portals/1/Documents/pubs/2017_China_Military_Power_Report.PDF
} 


\begin{tabular}{|c|c|c|}
\hline Level of War & Planning Event & Conceptual Basis \\
\hline Strategic & $\begin{array}{l}\text { - National Military } \\
\text { Strategy } \\
\text { - Theatre Strategy }\end{array}$ & $\begin{array}{l}\text { - Strategic } \\
\text { Approach/Theory e.g. } \\
\text { 'forward defense' }\end{array}$ \\
\hline Operational & $\begin{array}{l}\text { - Campaigns } \\
\text { - Major Operations }\end{array}$ & $\begin{array}{l}\text { - Operational concepts, } \\
\text { e.g. 'Air-Sea battle' }\end{array}$ \\
\hline Tactical & $\begin{array}{l}\text { - Battles } \\
\text { - Engagements } \\
\text { - Small Unit Actions }\end{array}$ & $\begin{array}{l}\text { - Small unit tactics, e.g. } \\
\text { 'fire and maneuver' }\end{array}$ \\
\hline
\end{tabular}

Underlying these planning processes are implicit or explicit conceptions of how military force operates to achieve operational and strategic objectives, what are known as operational concepts. US military doctrine describes these concepts as those which "examine military problems and propose solutions describing how the joint force, using military art and science, may operate to achieve strategic goals within the context of the anticipated future security environment. Joint concepts lead to military capabilities, both non-materiel and materiel, that significantly improve the ability of the joint force to overcome future challenges." ${ }^{42}$ These often change in anticipation of, or in reaction to, potential or actual technological developments. Blitzkrieg, for example, was a series of loosely connected ideas and concepts for the employment of combined arms maneuver warfare, a response to developing tank and communications technology.

42 Joint Chiefs of Staff, "JP1 - Doctrine for the Armed Forces of the United States" July 2017. xxvi http://www.jcs.mil/Portals/36/Documents/Doctrine/pubs/jp1_ch1.pdf 
Developing $A 2 A D$ technologies provides challenges for operational planning and execution but it is not yet apparent it provides a major impetus for more fundamental grand strategic change. As discussed earlier, integrated networks of sensors and weapons can potentially pose significant threats to a large number of US military assets and installations, not to mention its allies more generally. While A2AD technology is not an endgame in and of itself, it does create a 'cat-andmouse' situation with respect to technologies to counteract it. This in turn alters the cost-benefit ratio of given military options and so problematizes military action inside of A2AD envelopes. It is for this reason that extra resources alone are not a panacea. For example, consider that if operating an aircraft carrier within China's first island chain was regarded as unduly risky due to ASBM/ASCM threats than adding a second carrier to this scenario is not going to address the fundamental reasons for why this is so. In turn, this alludes to relative decline having transformative effects at a level of aggregation below that of grand strategic analysis.

Indeed, this can already be evidenced in the U.S. Navy's shift toward 'distributed lethality', an operational concept that requires lethality (for example, kinetic strike options) to be more widely spread across the fleet in order that it can provide "more strike options to joint-force commanders, provide another method to seize the initiative, and add battlespace complexity to an adversary's calculus." ${ }^{43}$ Thus providing the basis for small, dispersed multi-role formations of ships known 'Surface Action Groups' (SAGs). A similar change in operational thinking can also be seen in the US Air Force, who have also been experimenting with distributed diversionary airfields in the Asia Pacific in an attempt to lessen the vulnerability of forces concentrated in major bases throughout the region. In fact, in 2012 the U.S. Marines had already demonstrated proof of concept with the ability to clear disused runways and land both large transport aircraft and tactical, carrier based aircraft on them. ${ }^{44}$

\footnotetext{
${ }^{43}$ Vice Admiral Thomas Rowden et al. "Distributed Lethality" Proceedings Magazine Vol. 343 (2015) https://www.usni.org/magazines/proceedings/2015-01/distributed-lethality

44 "Marines Return to Historic Pacific Airfield" Time Magazine, May 30, 2012. http://nation.time.com/2012/05/30/marines-return-to-historic-pacific-airfield-2/ ; Antonia Rubio, "Marines complete arrested landing on Tinian” Marines, December 6, 2013.
} 
Moreover, some scholars have suggested that the principle of deterring regional hegemonic ambitions and reassuring allies does not necessarily have to entail full spectrum advantages over potential adversaries. One example that has gained traction in the literature has been the notion of a 'reverse A2AD' (R-A2AD) battle concept to facilitate a 'denial strategy' in order to achieve the anti-hegemonic strategic objectives of U.S. grand strategy. ${ }^{45}$ The central premise of utilising RA2AD operational concepts has been summarised as follows:

\begin{abstract}
"To curtail the ability of China's military to operate within the first island chain during a conflict (and thereby prevent the Chinese from prevailing in scenarios such as an attack on Taiwan or an effort to close or control key strategic waterways) by employing the same basic strategy and mix of capabilities - mines, mobile antiship missiles, and so on - that China itself has used to effectively push U.S. surface ships and aircraft away from its coast." $^{46}$
\end{abstract}

In essence, they believe that the core policy objectives that the National Military Strategy (NMS) need address - the capacity to 'deter, deny, and defeat state adversaries' - could be achieved via denying them the capacity to operate within their region and/or projecting force outside their region.

Additionally, there is much the United States could do at the level of theater strategy to dissuade and repel potential Chinese aggression in East Asia through employing a strategy of 'active denial'. This would expand this notion of R-A2AD to allied states in the region, with the US taking an active role in equipping and facilitating these states in establishing R-A2AD envelopes. ${ }^{47}$ Yet

http://www.hqmc.marines.mil/News/News-Article-Display/Article/553634/marines-complete-arrested-landings-on$\underline{\text { tinian/ }}$

${ }^{45}$ Stephen Brooks and William Wohlforth, "The Rise and Fall of the Great Powers in the Twenty-first Century: China's Rise and the Fate of America's Global Position" International Security 40:3 (2015/16) p,50

${ }^{46}$ Brooks and Wohlforth, "The Rise and Fall of the Great Powers," 50

${ }^{47}$ A theatre strategy is regionally oriented, and involves distilling national military objectives down to the regional level and constructing a coherent strategic approach to achieve them. It remains abstracted, albeit regionally tailored. 
such an operational concept, and its embedding in a theatre strategy, nonetheless proposes some considerable limitations. For example, an R-A2AD blockade would not necessarily deter enemy aggression nor deny it the achievement of its given objectives. While potentially denied freedom of maneuver in regional waters and airspace, an R-A2AD operational concept would nonetheless leave China capable of coercing regional states via blockade and/or missile attack. Biddle and Oelrich have argued that China could either "use coercive air or missile strikes against rival claimants' homelands to intimidate them into ceding a disputed stake" or "use A2/AD to impose a coercive blockade of the disputed islands (or their claimants)." 48 Neither of which are resolved by R-A2AD.

To put it simply, China could still aggress its neighbours and achieve the objectives of such aggression. In short, such an operational concept would be ineffective in facilitating stated U.S. strategic objectives. As the U.S. military themselves have noted,

\begin{abstract}
"it is our ability to globally project power that is a key military center of gravity... the United States must be capable and ready to address emerging challenger in a way that has been an advantage for American and allied forces for decades: the ability to project military force into an operational area with sufficient freedom of action to accomplish a designated mission." ${ }^{49}$
\end{abstract}

This, in turn, is what is at the core of the existent, albeit developing, Joint Concept for Access and Maneuver in the Global Commons (JAM-GC) pursued by the Pentagon. An evolution and refinement of the prior AirSea Battle (ASB) concept, JAM-GC is an operational concept which aims to facilitate the strategy of forward engagement in achieving its aims of deterring, denying, and defeating state adversaries. It differs from ASB in a no small way by revising the original objective

\footnotetext{
See for example, Michael Beckley, "The Emerging Military Balance in East Asia: How China's Neighbours Can Check Chinese Naval Expansion" International Security 42:2 (2017) pp, 78-119

${ }^{48}$ Biddle and Oelrich, "Future Warfare in the Western Pacific," 15-16

${ }^{49}$ Michael Hutchens et al. "Joint Concept for Access and Maneuver in the Global Commons: A New Joint Operational Concept"p, 135
} 
to 'disrupt/destroy/defeat' enemy A2AD capabilities, a principal of ASB which would entail the U.S. military to conduct deep strike operations in the Chinese mainland, directly operating within A2AD envelopes.

JAM-GC is therefore a product of the acknowledgement that "A2/AD capabilities evolved more quickly than anticipated and could only be dismantled at high levels of risk." ${ }^{\prime 50}$ The alternative proposed by JAM-GC is to permit access to portions of the global commons at any given time in order to "project power, and defeat an adversary attempting to deny freedom of action via the employment of A2/AD capabilities." Demanding that U.S. forces should seek to be distributable, resilient, mission tailorable, deploy assets of sufficient scale (range), and be able to operate for ample durations. ${ }^{51}$ Therefore, while some of the aforementioned options would help to enable such an operational change (principally a move from 'deep engagement plus' to 'deep engagement'), resource relocations or efficiencies are not sufficient to address what are fundamentally operational and perhaps even theatre level changes, and changes that only a combination of conceptual and practical operational innovation and technological evolution are capable of fundamentally addressing.

However, there are several possibilities currently available to the United States to deal with operational level change, as well as improve allied leathility and independent deterrent capabilities. Moreover, China's journey to a becoming a military superpower is variously constrained by a number of important factors and power asymmetries when compared with the United States. For example, China's overall technological development levels are lower than that of the US, particularly as it pertains to military technologies and as such, there are significant barriers to entry associated with attaining high end integrated military capabilities that cannot be constructed and perfected overnight, particularly in peacetime. Indeed, the United States has been conceptualizing, developing, and practising advanced forms of warfare for at least the last thirty years. Its investments and lessons learnt in joint, coalition warfare and practice are not

\footnotetext{
${ }^{50}$ Hutchens et al. "Joint Concept for Access and Maneuver in the Global Commons," 136

${ }^{51}$ Hutchens et al. "Joint Concept for Access and Maneuver in the Global Commons," 137
} 
easily replicated. ${ }^{52}$ Likewise, there are 'positional asymmetries' in the US-China military competition insofar as China is effectively physically surrounded by US allies. This geographic element is often underplayed, yet remains central to the fact that China has strong latent restraints on its capacity to either operate within the second island chain or physically project force against major US allies such as Japan or Taiwan.

As such, not only are US military advantages still strong, but operational innovation further permits flexibility and adaptation to changes that are brought on by technological innovation and changes in relative economic power. Nonetheless, over the medium to long term, it is likely that resource issues may emerge which would engage the necessity for more fundamental strategic re-thinks. As evidenced by our earlier analysis, this necessitates some discussion and analysis over that the role of uncertainty and change may play in the US-China military balance going forward. We explore some of these issues in the following section.

\section{Accounting for Uncertainty}

As we have discussed above, there are many trajectories that economic growth, military power, and military capability can take which in turn interact and develop in complex ways. The myriad of factors that could influence the development of these processes are extraordinarily difficult to model and predict, yet we can nonetheless identify a number of key disruptive factors that may cause, and have caused, substantial changes to relative economic and military power balances. Principally, we believe, the following three provide a rough framework,

1. Economic innovation

2. Military-technological disruptions

3. Political-economic dislocations

\footnotetext{
52 Brooks and Wohlforth, "The Rise and Fall of the Great Powers," pp, 40-42
} 
The first refers to technological developments or general economic changes such as the growth in computing or increased automation, changes in economic activity which have the potential to affect different economies in various ways, which may stimulate changes in relative growth dynamics. Similarly, military-technological disruptions occur when certain technological developments, and their subsequent integration into armed force equipment and doctrine, alter the military balance. These can range from the more pronounced, such as the military technological revolution (MTR), to somewhat more gradual developments relating to specific technologies, whether that be stealth or, conversely, sensor technology. Finally, and of a more immediate and pronounced importance, political-economic dislocations have the potential to fundamentally rewrite the geostrategic map. This could include such events as the collapse of the Soviet Union or, to a lesser degree, a pronounced economic crisis or period of stagnation.

All of these have the potential to change military and economic balances, and so make our prediction for future economic and security dynamics problematic. Conceptually, we may think of the future as a collection of potential alternative trajectories, only one of which is actually realised. Figure 3 visualises this, demonstrating a number of different trajectories of a hypothetical growth process. Doing this allows us to back out the distribution of different values at a given termination point, giving us a range of possibilities (the support) and their associated probabilities (the density). Conceptually, we can do something similar in our own assessments of economic growth or military development. While far from perfect, it rectifies some of the shortcomings of point prediction insofar as it permits an evaluation of a range of potential outcomes rather than the estimation of one sample path with the bias and precision issues that entails. 


\section{Figure 3}
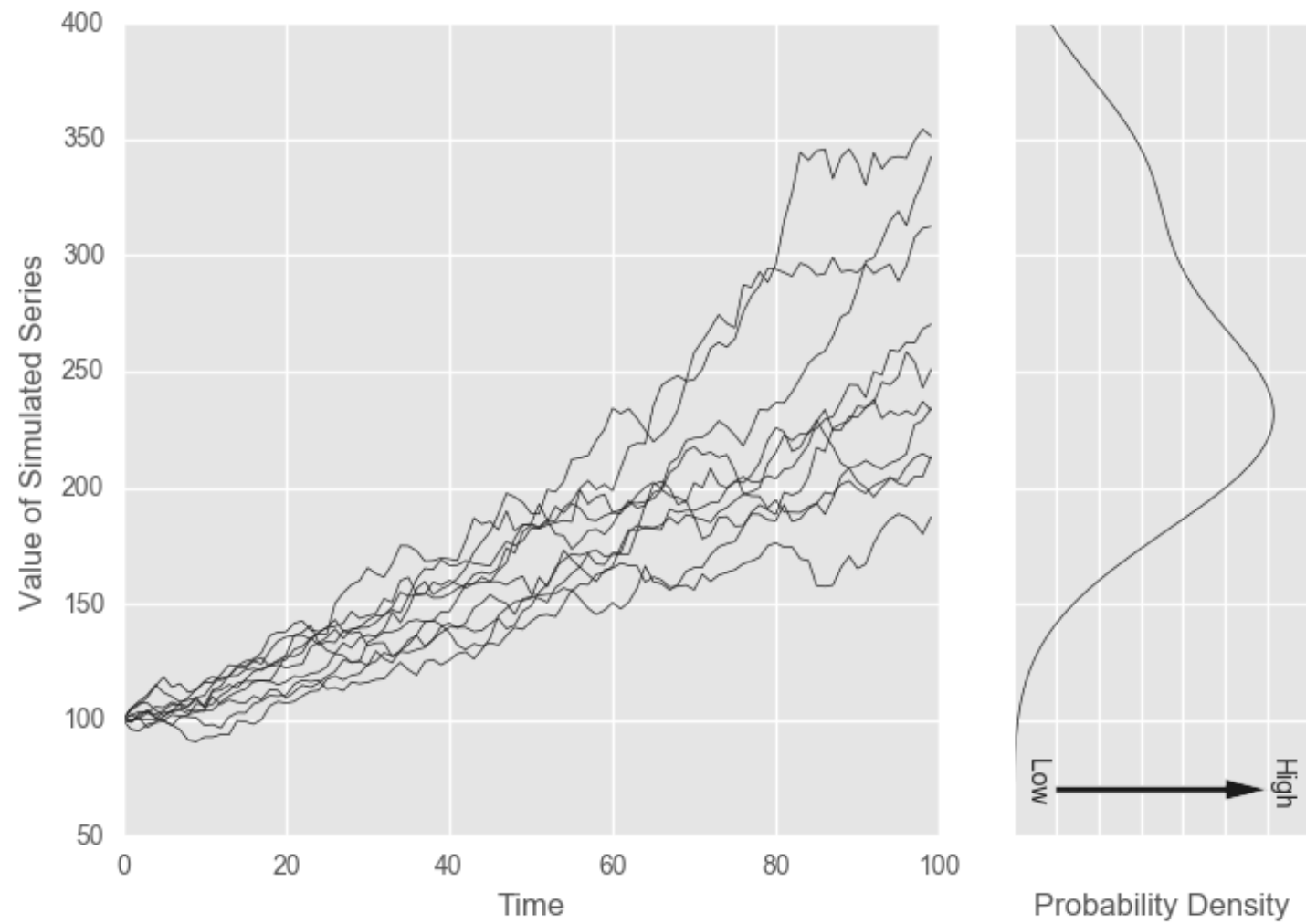

Probability Density

In turn, we suppose that such a process of evaluation can contribute towards strategic and operational planning by providing a guide to the potential scenarios that a specific strategy may be expected to operate under. For example, we could deduce a number of events of varying likelihood, severity, and potential outcome which would substantially influence American economic and military power going forward. We display some examples in table 4. As we can see, for the United States these scenarios are rather wide ranging and have various, likely interactive, effects. More importantly, these are not readily classifiable as risks or opportunities, instead they are better termed as uncertainties. That is, in the sense of 'knightian uncertainty' a risk whose associated probability cannot be accurately derived, which poses further complexities. 
negative and positive shocks respectively. It may not be a stretch to conjecture that this dilemma is one of the key contributing factors that put an end to the notion of 'AirSea battle', an operational concept that was exceedingly ambitious in nature and may well have performed poorly under continued technological and material erosion in the US-China military balance. Nonetheless, as was discussed earlier, the options available to the United States and its allies suggest that the objectives and broader approach of contemporary grand strategy, particularly its associated national military strategy, are potentially more durable than abstracted assessments of material balances allude. Although this does also suggest that this is contingent on sound operational planning and choices.

\section{Conclusion}

Despite the scope of the problem associated with increases in Chinese military capability, relative decline is having its most profound influences at levels of analysis which are more flexible and adaptable to change than national military strategy or grand strategy. Moreover, as we argued above, a number of US advantages are considerable, and its options more numerous, than often acknowledged. For example, its military resources and capabilities are far more developed and embedded than aggregate metrics may indicate. A significant implication of this is that much of this discussion is in fact far outside of the remit of grand strategic or even national military strategic levels of analysis, particularly as objectives and broad approach are concerned. That is, the empirical effects of relative decline have yet to build-up significantly enough to fundamentally undermine current strategic approaches. Indeed, strategic approach and objectives are abstract for a reason, and the current influences of relative decline have yet to manifest themselves as problems concerning aggregate resource levels.

Not only is it the case that specific details matter, but the undifferentiated fashion in which rise and decline is often presented is neither useful in describing current changes nor in proposing how to address them. Fundamentally, many calls for significant changes to US military strategic objectives or approach in light of relative decline remain more ideologically driven than determined by evolving systemic conditions. Problems posed at the operational level do not 
necessarily demand strategic level alterations, particularly as core objectives are concerned. As such, while restructured forms of deep engagement will help alleviate resource constraints in the medium to long term, their utility in addressing the operational changes brought on by relative decline are less apparent. This is not to say that changes to approach or objective may not be desirable, or perhaps even optimal when considered by differing sets of priorities and interests, but rather that current strategic objectives are yet to be innately undermined by changes brought on by America's relative material decline with respect to China.

References 
- Beckley, Michael. "China's Century? Why America's Edge Will Endure" International Security 36:3 (2011/12) pp. 41-78.

- Beckley, Michael. "Economic Development and Military Effectiveness" Journal of Strategic Studies 33:1 (2010) pp, 43-79.

- Beckley, Michael. "The Emerging Military Balance in East Asia: How China's Neighbours Can Check Chinese Naval Expansion" International Security 42:2 (2017) pp, 78-119

- Biddle, Stephen and Ivan Oelrich. "Future Warfare in the Western Pacific: Chinese Antiaccess/ Area Denial, U.S. AirSea Battle, and Command of the Commons in East Asia" International Security 41:1 (2016) pp. 7-48

- Brooks, Stephen and William Wohlforth. "The Rise and Fall of the Great Powers in the Twenty-first Century: China's Rise and the Fate of America's Global Position" International Security 40:3 (2015/16) pp, 7-53

- Brooks, Stephen, William Wohlforth, and John Ikenberry, “Don't Come Home, America: The Case Against Retrenchment" International Security 37:3 (2012/13) pp. 7-51

- Copeland, Dale. The Origins of Major War (Ithaca: Cornell University Press, 2000)

- Deni, John. "Rotational Deployments vs. Forward Stationing: How Can The Army Achieve Assurance and Deterrence Efficiently and Effectively?" Strategic Studies Institute and U.S. Army War College Press, August 2017.

- Erickson, Andrew et al. “Correspondence: How Good are China's Antiaccess/ Area-Denial Capabilities?" International Security 41:4 (2017) pp, 202-213

- Haddick, Robert. "China's Most Dangerous Missile (So Far)" War on the Rocks, July 2, 2014. http://warontherocks.com/2014/07/chinas-most-dangerous-missile-so-far/

- Haynes, Kyle. "Decline and Devolution: The Sources of Strategic Military Retrenchment" International Studies Quarterly 59 (2015) pp. 490-502

- Hutchens, Michael et al. "Joint Concept for Access and Maneuver in the Global Commons: A New Joint Operational Concept" Joint Force Quarterly 84 (2017) pp, 134-139

- Joint Chiefs of Staff, “JP1 - Doctrine for the Armed Forces of the United States” July 2017. http://www.jcs.mil/Portals/36/Documents/Doctrine/pubs/jp1_ch1.pdf 
- Joint Chiefs of Staff, "The National Military Strategy of the United States of America 2015" U.S. Department of Defense, June 2015. http://www.jcs.mil/Portals/36/Documents/Publications/2015_National_Military_Strate gy.pdf

- Karber, Phillip et al. "Assessing the Correlation of Forces: France 1940" BDM Corporation, BDM/W-79-560-TR, June 1979

- Krepinevich, Andrew and Barry Watts. The Last Warrior: Andrew Marshall and the Shaping of Modern American Defense Strategy (New York: Basic Books, 2015)

- Layne, Christopher. 'America's Middle East Grand Strategy After Iraq: The Moment for Offshore Balancing', European Journal of International Relations June 2007 vol. 13 no. 2 pp. 155-185

- Layne, Christopher. "From Preponderance to Offshore Balancing: America's Future. Grand Strategy,", International Security, Vol. 22 No. 1 (summer 1997), pp. 86-124

- Layne, Christopher. "The Unipolar Illusion: Why New Great Powers Will Rise" International Security 17:4 (1993) pp, 5-51

- Lippmann, Walter. US Foreign Policy: Shield of the Republic (Boston: Little, Brown and Company, 1943)

- Lostumbo, Michael. Overseas Basing of U.S. Military Forces: An Assessment of Relative Costs and Strategic Benefits (RAND: Santa Monica, 2013)

- MacDonald, Paul and Joseph Parent, "Graceful Decline? The Surprising Success of Great Power Retrenchment" International Security 35:4 (2011) pp. 7-44

- Mearsheimer, John and Stephen Walt. "The Case for Offshore Balancing: A Superior U.S. Grand Strategy" Foreign Affairs July/August (2016) pp, 70-83

- Mearsheimer, John. The Tragedy of Great Power Politics (New York: W. W. Norton \& Co, 2002)

- Muñoz, Carlo. "Pentagon Faces Hurdles Turning Trump's Afghanistan Strategy into Action." The Washington Times. The Washington Times, 29 Aug. 2017. Web. 30 Aug. 2017. http://www.washingtontimes.com/news/2017/aug/29/pentagon-faces-hurdlesturning-donald-trumps-afgha/ 
- O’Rourke, Ronald. “Navy Force Structure: A Bigger Fleet? Background and Issues for Congress" Congressional Research Service, November 9, 2016.

- Office of the Secretary of Defense, "Military and Security Developments Involving the People's Republic of China 2017" United States Department of Defense, 2017. https://www.defense.gov/Portals/1/Documents/pubs/2017_China_Military_Power_Re port.PDF

- Pape, Robert and James K. Feldman. Cutting the Fuse: The Explosion of Global Suicide Terrorism and How to Stop It (Chicago: University of Chicago Press, 2010)

- Posen, Barry. "The Case for Restraint," The American Interest, Vol. 3, No. 1, NovemberDecember 2007. http://www.the-american-interest.com/article.cfm?piece=331;

- Posen, Barry. "Restraining Order," The American Interest, Vol. 3, No. 3, (January-February 2008), pp. 94-97

- Posen, Barry. Restraint: A New Foundation for U.S. Grand Strategy (Ithaca: Cornell University Press, 2014)

- Preble, Christopher. The Power Problem: How American Military Dominance Makes Us Less Safe, Less Prosperous, and Less Free (Cornell: Cornell University Press, 2009)

- Rubio, Antonia. "Marines complete arrested landing on Tinian" Marines, December 6, 2013. http://www.hqmc.marines.mil/News/News-ArticleDisplay/Article/553634/marines-complete-arrested-landings-on-tinian/

- Rumsfeld, Donald. "The Global Posture Review of United States Military Forces Stationed Overseas" Testimony before the Senate Armed Services Committee. September 23, 2004. https://www.gpo.gov/fdsys/pkg/CHRG-108shrg23080/html/CHRG-108shrg23080.htm

- Schweller, Randall. Deadly Imbalances: Tripolarity and Hitler's Strategy of World Conquest (New York: Columbia University Press, 1998)

- Sevastopulo, Demetri. “China's Goldfinger general quizzed in corruption probe” Financial Times, January 15, 2014. https://www.ft.com/content/17808e4c-7dad-11e3-95dd00144feabdc0\#axzz2usRIG2I7

- SIPRI, "SIPRI Military Expenditure Database 2017" https://www.sipri.org/databases/milex 
- Time Magazine. "Marines Return to Historic Pacific Airfield", May 30, 2012. http://nation.time.com/2012/05/30/marines-return-to-historic-pacific-airfield-2/

- U.S. Department of Defense, "2018 Budget Request for European Reassurance Initiative Grows to \$4.7." 01 June 2017. Web. 30 Aug. 2017. https://www.defense.gov/News/Article/Article/1199828/2018-budget-request-foreuropean-reassurance-initiative-grows-to-47-billion/

- U.S. Navy, "A Cooperative Strategy for 21st Century Seapower" March 2015. http://www.navy.mil/local/maritime/150227-CS21R-Final.pdf

- Vice Admiral Thomas Rowden et al. "Distributed Lethality” Proceedings Magazine Vol. 343 (2015) https://www.usni.org/magazines/proceedings/2015-01/distributed-lethality

- Walt, Stephen M. “US Grand Strategy after the Cold War: Can Realism Explain It? Should Realism Guide It?" International Relations 32:1 (2018) pp. 3-22

- Walt, Stephen. Taming American Power: The Global Response to US Primacy (New York: W.W. Norton and Sons, 2005)

- Williams, Lyne and Susan Epstein. "Overseas Contingency Operations Funding: Background and Status" Congressional Research Service, February 7, 2017.

- Wohlforth, William et al. 'Testing Balance-of-Power Theory in World History' European Journal of International Relations, June 2007 vol. 13 no. 2. pp. 155-185.

- Yardley, Roland. "Increasing Aircraft Carrier Forward Presence: Changing the Length of the Maintenance Cycle" RAND Corporation, 2008

\section{Appendix 1 - Boxplot for Index Weighting}




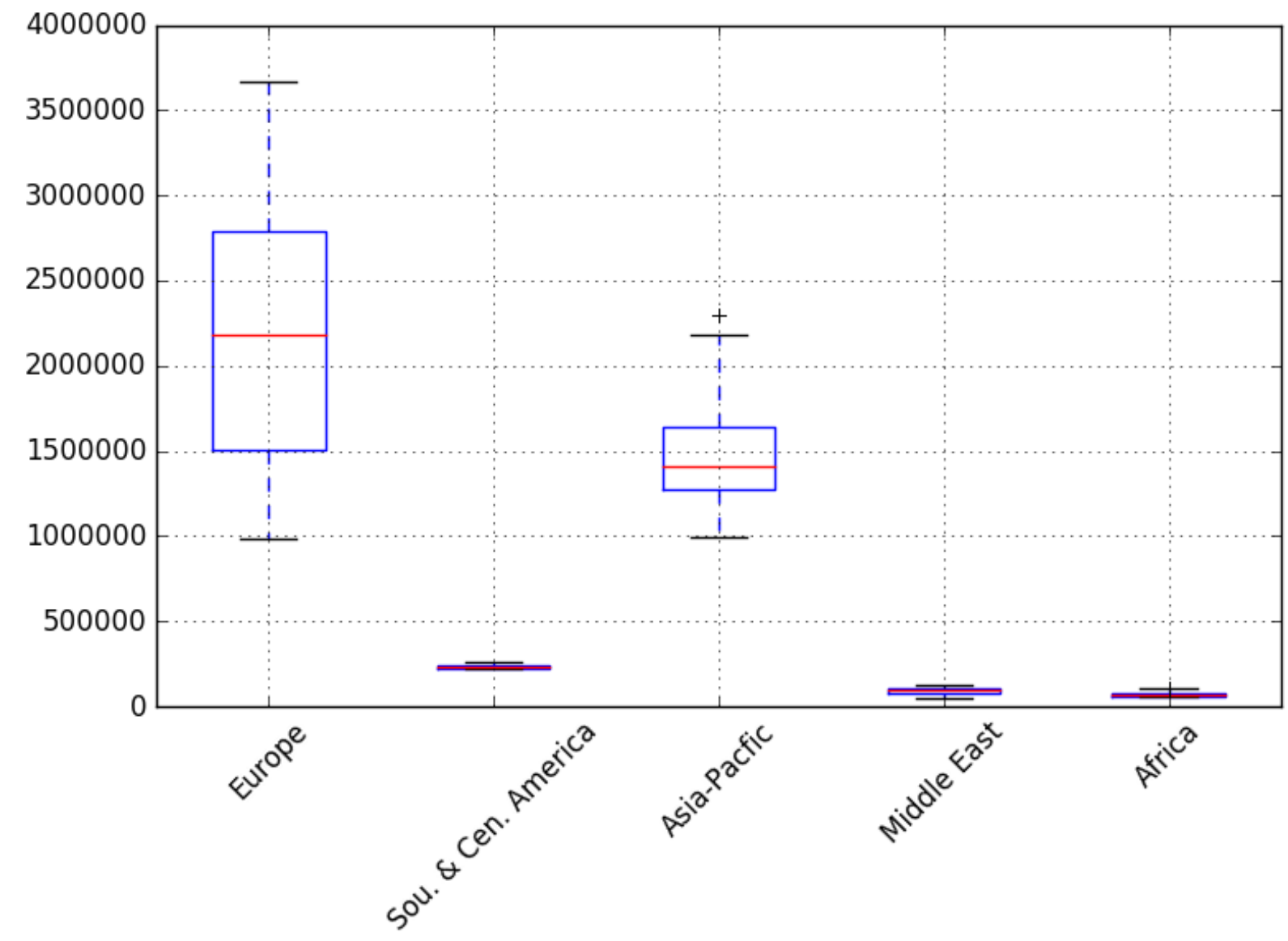

Appendix 2 
Qualitative factors including military doctrine and technological advancement play an important role in relative military balances. Indeed, attempts at more granular approaches to measuring military power have often proved empirically unreliable. The Weighted Effectiveness Indices/ Weapons Effectiveness Indicator (WEI)/ and Weighted Unit Value (WUV) approach is a good example. The method involved producing a score which combines the quantity and quality of weapon systems on two or more sides of a potentially conflict. The WEI score for a weapons system is scored relative to the standard US military weapon in each weapons category based on how they score across a range of characteristics. These WEI scores are then weighted and aggregated into WUVs. ${ }^{53}$ However, despite careful qualitative appraisal of the relevant capabilities of opposing weapon systems this method proved to have inferential limitations, performing with varying success in testing on real life examples. Principally, predictive failure occurred at aggregated levels of analysis, exactly what we would require. ${ }^{54}$ In many cases, and perhaps unsurprisingly, complex causal relationships conditioned the outcome of battles which WEI/WUV methodology could not foresee at higher levels of aggregation.

53 Phillip Karber et al. "Assessing the Correlation of Forces: France 1940” BDM Corporation, BDM/W-79-560TR, June 1979. pp, 1.1-1.2

${ }^{54}$ Karber et al. "Assessing the Correlation of Forces", 2.9-2.11 